\title{
Correction to: Failed preoperative vacuum bell therapy does not affect outcomes following minimally invasive repair of pectus excavatum
}

\author{
J. L. Muff ${ }^{1}$ - L. C. Guglielmetti ${ }^{2}$ S. J. Gros ${ }^{1}$ - L. Buchmüller ${ }^{1}$ - G. Frongia ${ }^{3} \cdot$ F.-M. Haecker ${ }^{4,5}$ - S. G. Holland-Cunz ${ }^{1}$. \\ T. de Trey $^{1} \cdot$ Raphael N. Vuille-dit-Bille ${ }^{1}$
}

Published online: 2 March 2022

(c) The Author(s) 2022

\section{Correction to: \\ Pediatric Surgery International (2021) 37:1429-1435 \\ https://doi.org/10.1007/s00383-021-04963-6}

In the original publication, author name Frank-Martin Haecker and the following affiliation was missing.

${ }^{4}$ Department of Pediatric Surgery, Children's Hospital of Eastern Switzerland, St. Gallen, Claudiusstrasse 6, CH-9006 St. Gallen, Switzerland

${ }^{5}$ Faculty of Medicine, University of Basel, 4056 Basel, Switzerland.

The original article has been corrected.

The original article can be found online at https://doi.org/10.1007/ s00383-021-04963-6.

Raphael N. Vuille-dit-Bille

Raphael.Vuille-dit-Bille@ukbb.ch

1 Department of Pediatric Surgery, University Children's Hospital of Basel, Spitalstrasse 33, 4056 Basel, Switzerland

2 Department of Visceral and Thoracic Surgery, Cantonal Hospital of Winterthur, Winterthur, Switzerland

3 Division of Pediatric Surgery, Department of General, Visceral and Transplantation Surgery, University Hospital Heidelberg, Heidelberg, Germany

4 Department of Pediatric Surgery, Children's Hospital of Eastern Switzerland, St. Gallen, Claudiusstrasse 6, 9006 St. Gallen, Switzerland

5 Faculty of Medicine, University of Basel, 4056 Basel, Switzerland
Open Access This article is licensed under a Creative Commons Attribution 4.0 International License, which permits use, sharing, adaptation, distribution and reproduction in any medium or format, as long as you give appropriate credit to the original author(s) and the source, provide a link to the Creative Commons licence, and indicate if changes were made. The images or other third party material in this article are included in the article's Creative Commons licence, unless indicated otherwise in a credit line to the material. If material is not included in the article's Creative Commons licence and your intended use is not permitted by statutory regulation or exceeds the permitted use, you will need to obtain permission directly from the copyright holder. To view a copy of this licence, visit http://creativecommons.org/licenses/by/4.0/.

Publisher's Note Springer Nature remains neutral with regard to jurisdictional claims in published maps and institutional affiliations. 